\title{
World travelling and speculative truth-telling: a review of Terra Nullius by Claire Coleman
}

\section{Chloe Michele}

University of Technology Sydney, Faculty of Arts and Social Sciences, PO Box 123, Ultimo NSW 2017, Australia. chloekmichele@gmail.com

DOI: https://doi.org/10.5130/nesais.v4i1.1511

I read Terra Nullius (Coleman 2017) after listening to an interview with Claire Coleman. She was intelligent, with a clear, striking voice that didn't hide her discomfort, but challenged us to feel it too. She said:

White people say that Australia is the lucky country, well...who is it lucky for? Because it's certainly not lucky for us. People always talk about closing the gap, well I think the gap that needs to be closed is the gap between the fiction of Australia and the reality of Australia. The fiction of Australia is terra nullius. The reality is that terra nullius was actually a lie. ('For us, happy endings feel dishonest' 2017)

For me, growing up white in Australia meant 'terra nullius' was always just some historical, abstract noun. I come from a family of Inner-West lefties and grew up in the John Howard era. I remember pushing my baby brother in his stroller across the Harbour Bridge in 2000, my mum holding an Aboriginal flag high above our heads. I remember standing in front of the school at assembly to acknowledge the Gadigal People of the Eora Nation, paying my respects to the Elders past and present. And when you grow up doing these things, it can make you feel too comfortable. Believing, yeah, I'm a good person. I care about Aboriginal and Torres Strait Islander peoples. I get it.

Terra Nullius is written for people like me. Well-intentioned white Australians who are clearly interested enough in Indigenous issues to pick up a book with the title Terra Nullius, but who will never be able to truly fathom the reality of how it feels to live as an Indigenous person in Australia. It's a startlingly clever work of speculative fiction, designed to unsettle the discursive myths white Australians rely upon to keep themselves from feeling guilty about the genocide our country was founded upon (Moreton-Robinson 2004). However, it was also written to provoke a new empathy in non-Indigenous Australians who "don't look at the suffering of Aboriginal people, and the Aboriginal people of a few generations ago and think 'what if that was my grandfather?"' ('For us, happy endings feel dishonest' 2017). Coleman uses clever speculative literary techniques to alter nonIndigenous perceptions of Australian land, challenging pervasive colonial discourses surrounding the legal fiction of terra nullius (Moreton-Robinson 2003), all the while reinforcing the underlying 
message that the invasion of Australia was not peaceful, and that it led to an apocalypse for Aboriginal people ('For us, happy endings feel dishonest' 2017).

Terra Nullius is set in an apocalyptic Australia, where binaries between human and alien have overtaken binaries between black and white, yet the first half is written with such ambiguity that it reads like a very familiar story (Whittaker 2018). The historical records Coleman fictionalises within the narrative imitate the bureaucratic indifference of Australia's existing colonial documents so perfectly that we'd have no reason to believe her descriptions of frontier violence, child removals, slavery and land theft were anything but factual accounts of Australia's past. It's not until we reach the second half that we're introduced to our new alien settler overlords who have invaded our country, refused to recognise our humanity, and ignored our rightful claim to country. For non-Indigenous readers, who up until this point had been tricked into imagining the story's subjugated victims as the 'other' (Hall 1997), it's an unexpected, horrifying twist. But for Indigenous readers like Whittaker (2018), "it serves a new horror in that it irreversibly cements the first invasion, although not without hope."

If speculative fiction can be defined as "a text that violates reality in some way, but nonetheless describes what is or may be possible," it can be argued that Terra Nullius violates reality not only by describing an apocalypse that may be possible, but by describing an apocalypse that has already occurred (Weaver 2011, p. 7). This point may not be clear to non-Indigenous readers who haven't considered Australia's violent colonial history as such. Coleman explains:

\begin{abstract}
Aboriginal people have actually lived an apocalyptic scenario. In 1788, people arrived and started killing everyone. We went from dominating a continent, being on our own here, to having less than $3 \%$ of the national population... it's probably one of the worst apocalypses in the history of the world. ('For us, happy endings feel dishonest' 2017)
\end{abstract}

For Indigenous readers who share Coleman's viewpoint and who may already consider themselves as living in a post-apocalyptic world, the full impact of Terra Nullius' twist may be dampened. This was the case for Whittaker (2018), who said, "As an Indigenous reader, I felt locked out of the surprise, revulsion and immersion that these earlier chapters could offer because the parallels...ran simply too close to the truth to be speculative for me." Coleman anticipated this reaction from her Indigenous readers, saying, "I really wrote Terra Nullius for non-Aboriginal people. Because we know how bad things are, we don't need to be taught" ( 'For us, happy endings feel dishonest' 2017). Speculative fiction is particularly useful for reframing colonial narratives, as it blurs the distinct, homogenous categories we use to make our worlds, defamiliarising the Australian landscape we take for granted (Wiebe 2013, pp. 182-183). Apocalyptic storytelling empowers the Indigenous author to simulate new futures to "disturb the linear time of progress" and "adjust the temporal logics that condemned black subjects to history" (Eshun 2003, p. 294).

For the non-Indigenous reader, the apocalyptic scenario that slowly unfolds throughout the narrative has a unique, transformative power which reveals new perspectives (Weaver 2011, p. 7) and takes them on a journey to a better understanding of the cultural pressures which created our own viewpoints (Lugones 1987, pp. 17-18). This compels non-Indigenous readers to outwardly gaze upon and contextualise their position within a settler society as they simultaneously unravel the trauma, past 
and present, of Indigenous Australians. Lugones (1987, p. 17) calls this process 'world-travelling', noting that "there are worlds we can travel to lovingly and travelling to them is a part of loving at least some of their inhabitants ...we can understand what is to be them and what it is to be ourselves in their eyes." This is what reading Terra Nullius felt like for me. Understanding, knowing and sympathising with Indigenous peoples about the atrocities they and their ancestors endured is one thing; seeing it through their eyes and feeling it in your heart is another. As a non-Indigenous person, I'll never be able to truly understand how Indigenous Australians living in colonised Australia feel, but Terra Nullius let me travel inside that world for just a moment and feel an even greater level of empathy than I had previously thought possible.

\section{References}

'For us, happy endings feel dishonest' 2017, podcast, It's Not A Race, ABC Radio National, Sydney, 17 November.

Coleman, C. 2017, Terra Nullius, Hachette Australia.

Eshun, K. 2003, 'Further considerations of Afrofuturism', CR: The New Centennial Review, vol. 3, no. 2, pp. 287-302. https://doi.org/10.1353/ncr.2003.0021

Hall, S. 1997, 'The spectacle of the other (excerpt)', Representation: cultural representations and signifying practices, Sage, London, pp. 225-41.

Lugones, M. 1987, 'Playfulness, “world”-travelling, and loving perception', Hypatia, vol. 2, no. 2, pp. 3-19. https://doi.org/10.1111/j.1527-2001.1987.tb01062.x

Moreton-Robinson, A. 2003, 'I still call Australia home: Indigenous belonging and place in a white postcolonizing society', Uprootings/regroundings: Questions of home and migration, pp. 23-40.

Moreton-Robinson, A. 2004, 'Whiteness, epistemology and Indigenous representation', Whitening race: Essays in social and cultural criticism, vol. 1, pp. 75-88.

Weaver, R. 2011, Apocalypse in Australian fiction and film: a critical study, vol. 28, McFarland.

Whittaker, A. 2017, 'Not As We Know It: Terra Nullius', Sydney Review of Books, 29 August, viewed 22 April 2018, < https://sydneyreviewofbooks.com/terra-nullius-claire-coleman/>.

Wiebe, L. 2013, 'Speculative matter: Generic affinities, posthumanisms and science-fictional imaginings'.

(c) (1) (C) 2018 by the author(s). This article is distributed under the terms and conditions of the Creative Commons Attribution license (http://creativecommons.org/licenses/by-nd/4.0/). 